\title{
OPTIMISING DRILLING PARAMETERS OF GFRP BY USING GREY RELATIONAL ANALYSIS
}

\author{
Shunmugesh $K^{1,2}$, Panneerselvam. $K^{2}$, Jospaul Thomas ${ }^{3}$ \\ ${ }^{I}$ Production Engineering Department, National Institute of Technology, Trichy, India \\ ${ }^{2}$ Mechanical Engineering Department, Viswajyothi College of Engg and Technology, Cochin, India \\ ${ }^{3}$ Mechanical Engineering Department, Viswajyothi College of Engg and Technology, Cochin, India
}

\begin{abstract}
Glass fiber reinforced polymer (GFRP) composite constitutes the current trends in the composite technology and machining of these materials make a challenging task. Drilling of GRPF can cause many problems if not optimized. In this study, composite undergo drilling and $L_{27}$ orthogonal array is used for determining delamination and surface roughness. Relationships are developed between parameters. In drilling, spindle speed, tool point angle and feed rate are combined to know the optimal parameters. Grey Relational Analysis was performed to observe the effect of parameters and its interaction. Experiment results reveal that spindle speed is the most significant factor while point angle contributes to the least.
\end{abstract}

Keywords: GRPF, Drilling, Grey Relational Analysis, Optimization

\section{INTRODUCTION}

The glass fiber-reinforced polymer composite makes its way up in the engineering due its high strength to weight ratio. These composites are highly used in transportation and construction applications. BharathiRaja et al. found the optimal machining parameters for the surface roughness in machining. Experimental analysis were carried out on aluminium material and studied effect of machining parameters such as cutting speed, feed, and depth of cut on the surface roughness and to obtain the desired surface roughness on face milling process. Mathematical model for surface roughness prediction using Particle Swarm Optimization (PSO) was developed on the basis of experimental results [1].

$\mathrm{Lu}$ et al. examined optimization design of the cutting parameters for high-speed end drilling on SKD61 tool steel. The main features selected to estimate the processes are tool life and metal removal rate, and the corresponding cutting parameters were spindle speed, feed per tooth, radial depth of cut, and axial depth of cut. Grey Relational Analysis was the tool used for optimization [2].

Panneerselvam et al. studied the performance of cutting tool on Glass Fibre Reinforced Polymer (GFRP). Grey Relational Analysis approach was the tool used for the study and optimized the machining parameters such as Tool Condition, number of flutes, cutting speed and feed rate on milling of GFRP. The outputs measured were surface delamination, machining forces, cutting torque and surface roughness [3].

Baharudin et al. expanded the Taguchi technique to study the optimal surface roughness on material AL6061. The milling parameters were assessed based on various factors such as spindle speed, feed rate and axial rake angle.
Analysis of Variance (ANOVA) was carried out by an orthogonal array $\mathrm{L}_{9}$ and found out signal-to-noise $(\mathrm{S} / \mathrm{N})$ ratio and identifies the significant factors that are affecting to the surface roughness [4].Faria et al. (2008) studied machining parameters such as thrust force and tool wear on carbon fiber epoxy composite(CFRP) by using steel coated carbide drill. Testing was conducted in an industrial setting and drilled up to 24,000 holes. Output parameters reviewed was difference in the thrust force and in geometry [5].

MohamadSyahmiShahromet al. studied Minimum Quantity Lubricant (MQL) and wet machining in milling processes of AISI 1060 Aluminum work material with the main objective of determining the effect of lubrication conditions on the surface roughness. The other parameters considered in the study are feed rate (FR), depth of cut (DOC) and cutting speed (CS).There are four levels in each parameters. He used the Taguchi method was used to predict the surface roughness. He found that, MQL produced better surface finish as compared to wet machining [6].

AzlanMohdZain et al. observed best possible effect of the radial rake angle of the tool, speed and feed rate, cutting conditions in effecting the surface roughness. Surface roughness should be minimum for optimization technique. In the study, Grey Relational Analysis was done to find the optimal result of the cutting conditions and the study proved that the GRA is capable of estimating the optimal cutting conditions [7]. Davim et al. (2004) examined cutting speed and feed rate as input parameters and surface roughness and delamination as output parameters. K10 carbide tools were used for the milling process. Output parameters such as surface roughness and delamination were predicted using response surface method (RSM). 
The main intentions behind is to study machinability features and applying GRA to find the optimum conditions. In the present study, K10 solid carbide drill is used for machining process and was machined under parameters, viz., spindle speed (A), point angle(B) and feedrate(C).

Table-1: Properties of the Laminate

\begin{tabular}{|l|l|l|l|l|}
\hline $\begin{array}{l}\text { Density } \\
\left(\mathrm{kg} / \mathrm{m}^{3}\right)\end{array}$ & $\begin{array}{l}\text { Weight } \\
\left(\mathrm{kg} / \mathrm{m}^{2}\right)\end{array}$ & $\begin{array}{l}\text { Tensile } \\
\text { Strength } \\
(\mathrm{MPa})\end{array}$ & $\begin{array}{l}\text { Tensile } \\
\text { Modulus } \\
(\mathrm{GPa})\end{array}$ & $\begin{array}{l}\text { Hardness } \\
(\mathrm{Hv})\end{array}$ \\
\hline 1204 & 9.534 & 71 & 1.81 & 22 \\
\hline
\end{tabular}

\section{EXPERIMENTAL INVESTIGATION}

Work piece used for the experiments is GFRP with epoxy resin composite. The size of the specimen used was 150 x150 x10 mm. The drilling process was carried out using TCA-70BV drilling Machine. The properties of the laminate are mentioned in Table 1. The cutting tool used for the machining was K10 solid carbide. The input parameters and their levels selected for the experimental design are listed below in Table 2 .

Table-2: factors and levels

\begin{tabular}{|l|l|l|l|l|}
\hline Symbol & $\begin{array}{l}\text { Machining } \\
\text { Parameters }\end{array}$ & Level 1 & Level 2 & Level 3 \\
\hline A & Speed (rpm) & 1000 & 2000 & 3000 \\
\hline B & $\begin{array}{l}\text { Point } \\
\text { Angle }\left(^{\circ}\right)\end{array}$ & 100 & 118 & 135 \\
\hline C & $\begin{array}{l}\text { Feed rate } \\
(\mathrm{m} / \mathrm{min})\end{array}$ & 0.05 & 0.1 & 0.15 \\
\hline
\end{tabular}

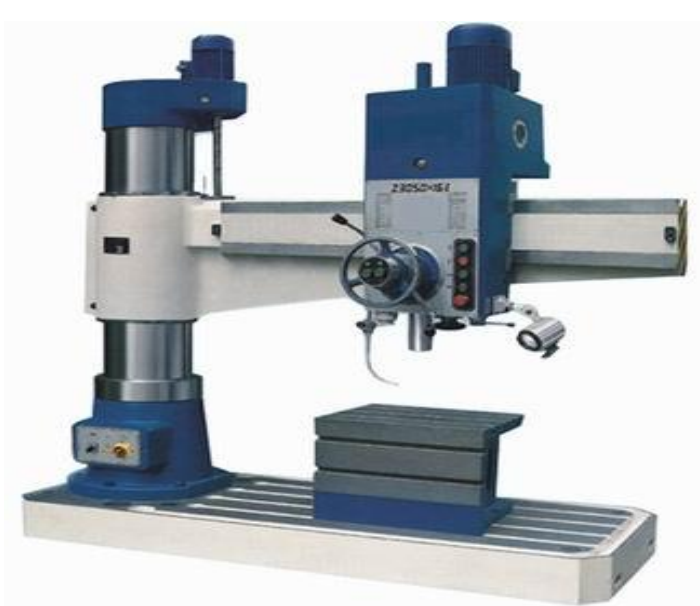

Fig-1: TCA-70BV Drilling Machine

\section{GREY RELATIONAL ANALYSIS}

In grey relational analysis, the level of similarity between elements touchstone the relative among elements. It finds out uncertain relation between one main factor and other factors given in a system. Black denotes zero information and white symbolize all information in grey relation technique. Grey is in between black and white. In the case that experiments are ambiguous or when the experimental method cannot be carried out exactly, grey analysis helps to compensate for the shortcoming in statistical regression.

\section{MACHINING PERFORMANCE MEASURES}

In this present study, Delamination Factor (DF) and Surface Roughness ( $\mathrm{Ra}$ ) were considered as the output parameter affecting the results of machining process by varying spindle speed, point angle and feed rate. Mitutoyo make Subsonic Surface Tester was used to find out the Surface Roughness. The Table 3 shows the orthogonal array $\left(\mathrm{L}_{27}\right)$ experimental design, input and output parameters.

Table-3: Orthogonal array (127) experimental design, input and output parameters

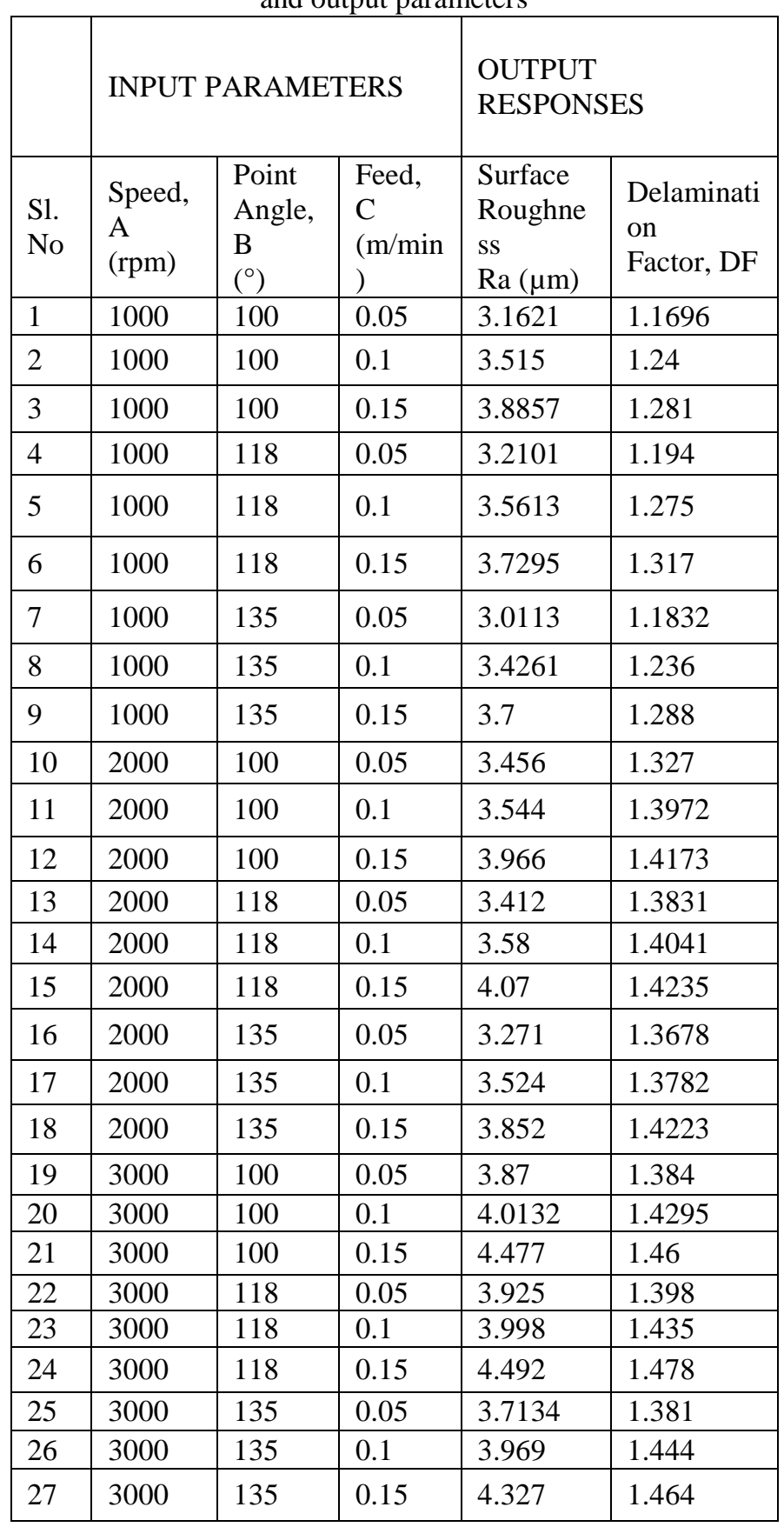




\section{RESULTS AND DISCUSSUIONS}

The experiments were carried out on the bases of $\mathrm{L}_{27}$ orthogonal array. Delamination factor and surface roughness were analysed on changing spindle speed, point angle and feed rate. The input parameters were optimized by using Grey Relational Analysis (GRA) for determining the optimal machining input parameters with the consideration of several performance features. Grey relational grade was found out and ranked for obtaining the optimal condition. Besides, this approach is feasible to obtain optimal machining parameters for a desired surface roughness and minimum delamination factor by GRA.

Table-4: Calculated Grey Relational Coefficient and Grey Relational Grade

\begin{tabular}{|c|c|c|c|c|c|c|}
\hline \multirow[b]{2}{*}{ Exp. No } & \multicolumn{3}{|c|}{ Experimental Design } & \multicolumn{2}{|c|}{ Grey Relational Coefficient } & \multirow{2}{*}{$\begin{array}{l}\text { Weighted Grey } \\
\text { Relational Grade }\end{array}$} \\
\hline & Speed, A(rpm) & $\begin{array}{l}\text { Point Angle, } \\
\mathbf{B}\left({ }^{\circ}\right)\end{array}$ & $\begin{array}{l}\text { Feed, } \\
\text { C(m/min })\end{array}$ & $\begin{array}{l}\text { Surface } \\
\text { Roughness, } \\
\text { Ra }(\mu \mathrm{m})\end{array}$ & $\begin{array}{l}\text { Delamination } \\
\text { Factor, DF }\end{array}$ & \\
\hline 1 & 1000 & 100 & 0.05 & 0.831 & 1.000 & 0.915 \\
\hline 2 & 1000 & 100 & 0.1 & 0.595 & 0.687 & 0.641 \\
\hline 3 & 1000 & 100 & 0.15 & 0.458 & 0.581 & 0.520 \\
\hline 4 & 1000 & 118 & 0.05 & 0.788 & 0.863 & 0.826 \\
\hline 5 & 1000 & 118 & 0.1 & 0.574 & 0.594 & 0.584 \\
\hline 6 & 1000 & 118 & 0.15 & 0.508 & 0.511 & 0.509 \\
\hline 7 & 1000 & 135 & 0.05 & 1.000 & 0.919 & 0.959 \\
\hline 8 & 1000 & 135 & 0.1 & 0.641 & 0.699 & 0.670 \\
\hline 9 & 1000 & 135 & 0.15 & 0.518 & 0.566 & 0.542 \\
\hline 10 & 2000 & 100 & 0.05 & 0.625 & 0.495 & 0.560 \\
\hline 11 & 2000 & 100 & 0.1 & 0.582 & 0.404 & 0.493 \\
\hline 12 & 2000 & 100 & 0.15 & 0.437 & 0.384 & 0.410 \\
\hline 13 & 2000 & 118 & 0.05 & 0.649 & 0.419 & 0.534 \\
\hline 14 & 2000 & 118 & 0.1 & 0.566 & 0.397 & 0.481 \\
\hline 15 & 2000 & 118 & 0.15 & 0.412 & 0.378 & 0.395 \\
\hline 16 & 2000 & 135 & 0.05 & 0.740 & 0.438 & 0.589 \\
\hline 17 & 2000 & 135 & 0.1 & 0.591 & 0.425 & 0.508 \\
\hline 18 & 2000 & 135 & 0.15 & 0.468 & 0.379 & 0.424 \\
\hline 19 & 3000 & 100 & 0.05 & 0.463 & 0.418 & 0.441 \\
\hline 20 & 3000 & 100 & 0.1 & 0.425 & 0.372 & 0.399 \\
\hline 21 & 3000 & 100 & 0.15 & 0.336 & 0.347 & 0.341 \\
\hline 22 & 3000 & 118 & 0.05 & 0.448 & 0.403 & 0.425 \\
\hline 23 & 3000 & 118 & 0.1 & 0.429 & 0.367 & 0.398 \\
\hline 24 & 3000 & 118 & 0.15 & 0.333 & 0.333 & 0.333 \\
\hline 25 & 3000 & 135 & 0.05 & 0.513 & 0.422 & 0.468 \\
\hline 26 & 3000 & 135 & 0.1 & 0.436 & 0.360 & 0.398 \\
\hline 27 & 3000 & 135 & 0.15 & 0.360 & 0.344 & 0.352 \\
\hline
\end{tabular}

Table-5: Response Table for Grey Relational Grade Level Factor

\begin{tabular}{|l|l|l|l|}
\hline S1 No & $\begin{array}{l}\text { Spindle } \\
\text { Speed(A) }\end{array}$ & $\begin{array}{l}\text { Point } \\
\text { Angle(B) }\end{array}$ & Feed Rate(C) \\
\hline 1 & $\mathbf{0 . 6 8 5 1}$ & 0.5243 & $\mathbf{0 . 6 3 5 2}$ \\
\hline 2 & 0.4881 & 0.4984 & 0.5079 \\
\hline 3 & 0.3950 & $\mathbf{0 . 5 4 5 5}$ & 0.4251 \\
\hline
\end{tabular}

\section{CONCLUSIONS}

Grey relational Analysis was used to discover optimal machining parameter. With GRA, we determine found grey relational grade and finally ranked it. Since the minimum value of surface roughness and minimum delamination factor is ideal for the machining operation, the grey relational coefficients for the same given in table IV are obtained using the formula: 
Grey Relational Coefficient $=\frac{=(\max (x)-x)}{(\max (x)-\min (x))}$

Machining Parameters namely Spindle Speed (A), Point Angle (B), Feed $\operatorname{Rate}(\mathrm{C})$ were optimized to meet the objective. From the study, the following conclusions are drawn:

- The observation result shows that the primary factor affecting the surface roughness is spindle speed, subsequently followed by feed rate and point angle. Also spindle speed is the major factor affecting the delamination factor.

- The optimized control factors for minimizing the Surface roughness $\mathrm{Ra}$ and delamination factor DF were Spindle speed $\mathrm{A}_{1}=1000 \mathrm{rpm}$, Point Angle $\mathrm{B}_{3}=135^{\circ}$, Feed Rate $\mathrm{C}_{1}=0.5 \mathrm{~m} / \mathrm{min}$.

\section{REFERENCES}

[1] S. Bharathi Raja and N. Baskar, "Application of Particle Swarm Optimization technique for achieving desired milled surface roughness in minimum machining time", Expert Systems with Applications Issue. 39, 2012, pp. 5982-5989.

[2] H.S. Lu, C.K. Chang, N.C. Hwang and C.T. Chung, "Grey relational analysis coupled with principal component analysis for optimization design of the cutting parameters in high-speed end milling", Journal of materials processing technology, Issue. 209, 2009, pp. 3808-381.

[3] K.Panneerselvam, K.Pradeep and P.Asokan, "Optimization of End Milling for Glass Fiber Reinforced Plastic (GFRP) using Grey Relational Analysis, ProcediaEngg Issue 38, 2012, pp. 39623968.

[4] B.T.H.T Baharudin, M.R. Ibrahim, N. Ismail, Z. Leman, M.K.A. Ariffin and D.L. Majid, "Experimental Investigation of HSS Face Milling to AL6061 using Taguchi Method", Procedia Engineering Issue. 50, 2012, pp. 933 - 941.

[5] Faria, P.E., Campos, R.F., Abrao, A.M., Godoy, G.C.D. and Davim, J.P. (2008), "Thrust force and wear assessment when drilling glass fibre-reinforced polymeric composite", Journal of Composite Materials, Vol. 42 No. 14, pp. 1401-1414.

[6] MohamadSyahmiShahrom, Nafrizuan Mat Yahya and Ahmad RazlanYusoff, "Taguchi Method Approach on Effect of Lubrication Condition on Surface Roughness in Milling Operation", Procedia Engineering Issue. 53, 2013, pp. 594 - 599.

[7] AzlanMohdZain, HabibollahHaron and Safian Sharif, "Application of GA to optimize cutting conditions for minimizing surface roughness in end milling machining process", Expert Systems with Applications Issue. 37, 2010, pp. 4650-4659.

[8] Davim, J., Reis, P. and Antonio, C. (2004), “A study on milling of glass fibre reinforced plastics manufactured by hand-lay up using statistical analysis (ANOVA)", Composite Structures, Vol. 64 No. 4, pp. 493-500. 